\title{
4'-Chloro-3,5-dihydroxystilbene, a resveratrol derivative, induces lung cancer cell death
}

\author{
Jin-yi WU ${ }^{1, \#}$, Kun-wei TSAl ${ }^{2, \#}$, Jia-jen SHEE ${ }^{3}$, Yi-zhen $\mathrm{LI}^{1}$, Ching-hsein $\mathrm{CHEN}^{1}$, Jing-jing CHUANG ${ }^{4}$, Yi-wen LIU ${ }^{1, *}$ \\ ${ }^{1}$ Graduate Institute of Biomedical and Biopharmaceutical Sciences, ${ }^{4}$ Department of Microbiology and Immunology, College of Life \\ Sciences, National Chiayi University, Chiayi, Taiwan 60004, China; ${ }^{2}$ Department of Internal Medicine, Buddhist Tzuchi Dalin General \\ Hospital, Dalin Town, Chiayi, Taiwan 62247, China; ${ }^{3}$ Division of Urology, Department of Surgery, Chang Gung Memorial Hospital, Chiayi, \\ Taiwan 61363, China
}

\begin{abstract}
Aim: To examine the antitumor effect of 4'-chloro-3,5-dihydroxystilbene, a resveratrol derivative, on lung adenocarcinoma A549 cells. Methods: The cytotoxic $\mathrm{IC}_{50}$ was determined by direct cell counting. Flow cytometry, monodansylcadaverine (MDC) staining, transfection, Western blot and a proteasome activity assay were used to study the cellular mechanism of 4'-chloro-3,5-dihydroxystilbene. A xenograft nude mouse model was used to analyze the antitumor effect in vivo.

Results: 4'-Chloro-3,5-dihydroxystilbene induced a rapid and persistent increase in the intracellular reactive oxygen species in the cells, but the cell death could not be inhibited by two antioxidant agents. The derivative caused sub- $\mathrm{G}_{1}$ formation, a decrease in the mitochondria membrane potential and poly (ADP-ribose) polymerase degradation, and the caspase inhibitor Z-VAD-FMK could partially prevent cell death. It also induced a significant increase in intracellular acidic vacuoles, LC3-II formation and intracellular GFP-LC3 aggregation. An autophagic inhibitor partially reversed cell death. Additionally, 4'-chloro-3,5-dihydroxystilbene induced the accumulation of ubiquitinated conjugates and inhibited proteasome activity in cells. In an in vivo study, 4'-chloro-3,5-dihydroxystilbene retarded tumor growth in nude mice.
\end{abstract}

Conclusion: These data suggest that the resveratrol derivative 4'-chloro-3,5-dihydroxystilbene could be developed as an anti-tumor compound.

Keywords: 4'-chloro-3,5-dihydroxystilbene; resveratrol derivative; antitumor effects; apoptosis; lung adenocarcinoma A549 cells

Acta Pharmacologica Sinica (2010) 31: 81-92; doi: 10.1038/aps.2009.182

\section{Introduction}

In the search for new cancer chemopreventive and chemotherapeutic agents over the past several years, the development of novel agents from the fruits and vegetables consumed by humans has been a desirable goal. Resveratrol (3,5, $4^{\prime}$ trihydroxy-trans-stilbene) is one of the naturally occurring phytoalexins produced by a wide variety of plants, such as grapes, peanuts, and mulberries, in response to stress, injury, ultraviolet, irradiation or fungal infection ${ }^{[1]}$. Therefore, the biological function of resveratrol is thought to be protection of the plants from fungal attack and environmental stress. It has been reported that tobacco plants reengineered with stilbene synthase genes are more resistant to infection by Botrytis cinerea $^{[2]}$. In the study of its biological function in animals and

\footnotetext{
\# The first two authors contributed equally to this work.

* To whom correspondence should be addressed.

E-mail ywlss@mail.ncyu.edu.tw

Received 2009-06-22 Accepted 2009-11-19
}

humans, resveratrol has been reported to play a role in the prevention of heart disease $\mathrm{e}^{[3]}$, the reduction of eicosanoid synthesis in macrophages ${ }^{[4]}$ and the inhibition of LDL oxidation ${ }^{[5]}$. Additionally, resveratrol also exhibits cancer chemopreventive activity in the stages of tumor initiation, promotion and $\operatorname{progression}^{[6]}$.

In addition to its chemopreventive effect, resveratrol also has a chemotherapeutic effect. In an in vitro study, resveratrol inhibited the growth of several tumor cell lines, including human promyelocytic leukemia cells, human breast cancer cells, human colon cancer cells, and human lung carcinoma cells $^{[7]}$. In an in vivo animal study, resveratrol was also shown to have an anti-tumor effect ${ }^{[8]}$. In view of resveratrol's anti-tumor potential, it is reasonable to design new chemotherapeutic agents using resveratrol as a prototype. It has been reported that a resveratrol derivative, 3,4,5,4'-tetramethoxystilbene, has stronger anti-proliferative properties in human colon cancer cells $^{[9]}$. Therefore, we synthesized a series of methoxy groupmodified stilbenes and tested their cytotoxicity in human lung 
cancer cells (supplementary information). On the other hand, the addition of a halogen group during the structural modification of resveratrol has seldom been reported. Based on the fact that the water solubility of a halogen is better than that of a methoxyl group, we have also synthesized a series of halogen group-modified stilbenes and found that 4 '-chloro-3,5-dihydroxystilbene has better anti-tumor activity (supplementary information).

Lung cancer is the leading cause of cancer-related death in the world and in Taiwan ${ }^{[10,11]}$. Therefore, we have studied the cytotoxicity of 4'-chloro-3,5-dihydroxystilbene in human lung adenocarcinoma A549 cells, elucidated the molecular mechanism of cell death and verified its effect in vivo.

\section{Materials and methods Chemicals}

F12 Kaighn's medium (F12K), bovine serum and Lipofectamine 2000 were purchased from Invitrogen (Grand Island, NY). 1-[4,5-Dimethylthiazol-2-yl]-3,5-diphenylformazan (MTT), anti- $\beta$-actin antibodies, propidium iodide (PI), 2,7dichlorofluorescin (DCF), N-acetyl-L-cysteine (NAC), glutathione, monodansylcadaverine (MDC), acridine orange, MG132, 3-methyladenine (3-MA), 4-(2-aminoethyl)benzenesulfonyl fluoride hydrochloride (AEBSF), N-CBZ-PHE-ALA fluoromethyl ketone (Z-FA-FMK), N-tosyl-L-phenylalanine chloromethyl ketone (TPCK) and $N^{\alpha}$-tosyl-L-lysine chloromethyl ketone hydrochloride (TLCK) were purchased from SigmaAldrich (St Louis, MO). [L-3-trans-(Propylcarbamoyl)oxirane2-carbonyl]- $L$-isoleucyl- $L$-proline methyl ester (CA074-Me) was purchased from the Peptide Institute (Osaka, Japan). Antibodies against cyclins, p21, Bcl-2, and Bax were purchased from Lab Vision (Fremont, CA). The antibody against procaspase-3 was purchased from Active Motif (Carlsbad, CA). The antibody against poly(ADP-ribose) polymerase (PARP) was purchased from Cell Signaling Technology (Beverly, MA). The SuperSignal West Pico Chemiluminescent Substrate was obtained from Pierce (Rockford, IL). The PRO-PREP ${ }^{\mathrm{TM}}$ Protein Extraction Solution was from iNtRON Biotechnology (Kyungki-Do, Korea). The Bio-Rad protein assay kit was purchased from Bio-Rad (Hercules, CA). Fluorogenic peptide substrates for the proteasome activity assay were purchased from Biomol (Butler Pike, PA).

\section{Cell culture}

Human non-small-cell lung adenocarcinoma A549 cells were obtained from the Bioresource Collection and Research Center (Hsinchu, Taiwan), and cultured in F12K supplemented with $10 \%$ heat-inactivated fetal bovine serum. Cells were maintained at $37^{\circ} \mathrm{C}$ in a humidified atmosphere with $5 \% \mathrm{CO}_{2}$.

\section{Trypan blue dye exclusion method}

The cell number was determined by direct cell counting. A549 cells were cultured in 24 -well plates at a density of $2 \times 10^{4}$ cells/ well for $24 \mathrm{~h}$ and then incubated with various concentrations of resveratrol or 4'-chloro-3,5-dihydroxystilbene for 2 days. The cells were then detached by trypsin-EDTA, stained with trypan blue dye and counted with a hemocytometer. The result was expressed as a percentage relative to the solventtreated control incubations, and the $\mathrm{IC}_{50}$ values were calculated.

\section{Measurement of intracellular reactive oxygen species (ROS)}

The production of intracellular ROS was detected by flow cytometry using DCFH-DA. A549 cells were cultured in $60-\mathrm{mm}$ tissue culture dishes at a density of $8 \times 10^{5}$ cells/dish for $24 \mathrm{~h}$ and then treated with DMSO or 4'-chloro-3,5-dihydroxystilbene for various amounts of time. After treatment, cells were treated with $10 \mu \mathrm{mol} / \mathrm{L}$ DCFH-DA for $30 \mathrm{~min}$ in the dark, washed once with PBS, detached by trypsinization, collected by centrifugation, and resuspended in PBS. The intracellular ROS, which are indicated by the fluorescence of dichlorofluorescin (DCF), were measured with a Becton-Dickinson FACScan flow cytometer using CellQuest software.

\section{Measurement of cellular membrane integrity}

Cellular membrane integrity was detected by PI staining. A549 cells were cultured in 60-mm tissue culture dishes for $24 \mathrm{~h}$ and then incubated with various inhibitors for $60 \mathrm{~min}$. DMSO or 4'-chloro-3,5-dihydroxystilbene was then added to the cells for the indicated times. After treatment, trypsinized cells were resuspended in PBS and stained for 10 min with 5 $\mu \mathrm{g} / \mathrm{mL}$ of PI. The stained cells were excited by exposure to an argon laser at $488 \mathrm{~nm}$, and the fluorescence emission was collected at $580 \mathrm{~nm}$. At least 10000 cells were counted with a Becton-Dickinson FACScan flow cytometer using CellQuest software. Living cells prevent the entrance of propidium iodide, indicating complete cellular membrane integrity, and dead cells are stained by propidium iodide, indicating damage to the cellular membranes.

\section{Cell cycle analysis}

A549 cells were cultured in 100-mm tissue culture dishes at a density of $1 \times 10^{6}$ cells/dish for $24 \mathrm{~h}$ and then treated with 80 $\mathrm{mol} / \mathrm{L} 4$ '-chloro-3,5-dihydroxystilbene for various amounts of time. After treatment, cells were collected and washed with PBS, fixed with a PBS-methanol (1:2, volume/volume) solution, and stored at $4{ }^{\circ} \mathrm{C}$ for at least $18 \mathrm{~h}$. Following two more PBS washes, the cell pellets were stained with the fluorescent probe solution containing PBS, $40 \mu \mathrm{g} / \mathrm{mL}$ PI, and $40 \mu \mathrm{g} / \mathrm{mL}$ DNase-free RNaseA for $30 \mathrm{~min}$ at room temperature in the dark. DNA fluorescence of the PI-stained cells was evaluated by excitation at $488 \mathrm{~nm}$ and detected through a 630/22-nm bandpass filter using a Becton-Dickinson FACScan flow cytometer. A minimum of 10000 cells were analyzed per sample, and the DNA histograms were gated and analyzed further using Modfit software to estimate the percentage of cells in various phases of the cell cycle.

\section{Measurement of mitochondria membrane potential}

Mitochondria membrane potential (MMP) was detected by flow cytometry using rhodamine123 fluorescent dye (Ex/ $\mathrm{Em}=430 \mathrm{~nm} / 535 \mathrm{~nm})$. A549 cells were cultured in 60-mm tis- 
sue culture dishes at a density of $8 \times 10^{5}$ cells/dish for $24 \mathrm{~h}$ and then treated with $80 \mu \mathrm{mol} / \mathrm{L} 4^{\prime}$-chloro-3,5-dihydroxystilbene for $24 \mathrm{~h}$ and $48 \mathrm{~h}$. After treatment, the culture medium was replaced with fresh medium containing $5 \mu \mathrm{mol} / \mathrm{L}$ rhodamine123 and the cells were incubated for $30 \mathrm{~min}$ in the dark. After the incubation step, the cells were washed with PBS, detached by trypsinization, collected by centrifugation, and resuspended in PBS. The MMP, as indicated by the fluorescence level of rhodamine123, was measured with a BectonDickinson FACScan flow cytometer using CellQuest software.

\section{Measurement of acidic vacuoles by MDC staining and acridine} orange staining

A549 cells were cultured in 100-mm tissue culture dishes at a density of $1 \times 10^{6}$ cells/dish for $24 \mathrm{~h}$ and then treated with $80 \mu \mathrm{mol} / \mathrm{L} \mathrm{4}$ '-chloro-3,5-dihydroxystilbene for another $24 \mathrm{~h}$. After treatment, the culture medium was replaced with fresh medium containing $50 \mu \mathrm{mol} / \mathrm{L} \mathrm{MDC} \mathrm{or} 1 \mu \mathrm{g} / \mathrm{mL}$ of acridine orange and the cells were incubated for $30 \mathrm{~min}$ in the dark. For MDC staining, cells were washed with PBS and photos were taken under a fluorescent microscope. For acridine orange staining, cells were detached by trypsinization, collected by centrifugation, and resuspended in PBS. The fluorescence level of acridine orange was measured with a BectonDickinson FACScan flow cytometer using CellQuest software.

\section{Measurement of LC3 localization by immunofluorescence microscopy}

The green fluorescent protein-tagged autophagic marker microtubule-associated protein 1 light chain 3 (GFP-LC3) plasmid $^{[12]}$ was transiently transfected into A549 cells using Lipofectamine ${ }^{\mathrm{TM}} 2000$ according to the manufacturer's instruction. Cells were replated $16 \mathrm{~h}$ before transfection at a density of 5000 cells per $1 \mathrm{~mL}$ of culture medium in a 12-well plastic dish. In transfection, Lipofectamine ${ }^{\mathrm{TM}} 2000$ was incubated with GFP-LC3 (1 $\mu \mathrm{L}$ Lipofectamine ${ }^{\mathrm{TM}} 2000 / 0.5 \mu \mathrm{g}$ DNA/well) in $0.1 \mathrm{~mL}$ of OPTI-MEM for $20 \mathrm{~min}$ at room temperature. The mixture was added drop by drop to the cells and then incubated for $6 \mathrm{~h}$. The DNA/Lipofectamine ${ }^{\mathrm{TM}} 2000$ medium was replaced by $1 \mathrm{~mL}$ of fresh culture medium and the cells were cultured for another $18 \mathrm{~h}$. Then, $80 \mu \mathrm{mol} / \mathrm{L} 4^{\prime}$-chloro-3,5-dihydroxystilbene was added to the cells in order to observe GFPLC3 localization by immunofluorescence microscopy.

\section{Proteasome activity assay}

A549 cells were treated with DMSO, 4'-chloro-3,5-dihydroxystilbene or proteasome inhibitor MG132 for 30 to $90 \mathrm{~min}$. Cell lysates were collected and $10 \mu \mathrm{g}$ of each was incubated for $2 \mathrm{~h}$ at $37^{\circ} \mathrm{C}$ with $40 \mu \mathrm{mol} / \mathrm{L}$ fluorogenic peptide substrate (Suc-Leu-Leu-Val-Tyr-AMC for chymotrypsin-like, Ac-GlyPro-Leu-Asp-AMC and Z-Leu-Leu-Glu-AMC for caspase-like, and Boc-Leu-Arg-Arg-AMC and Ac-Arg-Leu-Arg-AMC for trypsin-like) in $100 \mu \mathrm{L}$ of assay buffer $(20 \mathrm{mmol} / \mathrm{L}$ Tris- $\mathrm{HCl}$, $\mathrm{pH}$ 8.0). The hydrolyzed AMC was measured by a fluorometer with an excitation filter of $360 \mathrm{~nm}$ and an emission filter of $460 \mathrm{~nm}$.

\section{Animal model}

Female nude mice aged five weeks were provided by the National Laboratory Animal Center (Taipei, Taiwan), and maintained at our animal care facility for one week prior to use. The mice were kept in a limited access area at a controlled room temperature with food and water provided ad libitum. The mice were divided into two groups for two different experiments (vehicle only and $50 \mathrm{mg} / \mathrm{kg} 4^{\prime}$-chloro-3,5dihydroxystilbene). All experiments were approved by the Institutional Animal Care and Use Committee of National Chiayi University.

\section{Statistical analysis}

Three or more separate experiments were conducted. Statistical analysis was performed with Student's $t$-test. The animal study was analyzed by one-way ANOVA followed by Tukey's test. A $P<0.05$ was considered to indicate a significant difference between the treated and control groups.

\section{Results}

Effect of resveratrol and 4'-chloro-3,5-dihydroxystilbene on cell viability

When comparing the cytotoxicity of 4 '-chloro-3,5-dihydroxystilbene to that of resveratrol in $\mathrm{A} 549$ cells, the $\mathrm{IC}_{50}$ of resveratrol $(25.5 \mu \mathrm{mol} / \mathrm{L})$ is about 1.5 times greater than that of 4 '-chloro-3,5-dihydroxystilbene $(17.4 \mu \mathrm{mol} / \mathrm{L})$, and the maximum cytotoxic activity reached was $100 \%$ with 4 '-chloro-3,5dihydroxystilbene, but only $80 \%$ with resveratrol (Figure 1A). In addition to the A549 cells, 4'-chloro-3,5-dihydroxystilbene also showed higher cytotoxicity than resveratrol in two other lung cancer cell lines, NCI-H23 and NCI-H1299 (Figure 1A). A549 cells treated with $100 \mu \mathrm{mol} / \mathrm{L}$ resveratrol displayed a shrunken shape at $24 \mathrm{~h}$ and started to detach at $48 \mathrm{~h}$ (Figure 1B). With $80 \mu \mathrm{mol} / \mathrm{L} 4$ '-chloro-3,5-dihydroxystilbene, the cells showed vacuolation at $24 \mathrm{~h}$ and became almost rounded and detached after $48 \mathrm{~h}$ of treatment (Figure 1B). This result suggested that 4 '-chloro-3,5-dihydroxystilbene was more potent than resveratrol and that its cytotoxic mechanism might be different from that of resveratrol in human lung carcinoma cells. 4'-Chloro-3,5-dihydroxystilbene induced intracellular ROS elevation that was not the main inducer of cell death. Because ROS have been reported to induce cytotoxicity in cancer cells ${ }^{[13]}$, we analyzed the effect of $4^{\prime}$-chloro-3,5-dihydroxystilbene on the intracellular ROS production by the DCFH-DA staining method. The increase in intracellular ROS occurred after $1 \mathrm{~h}$ of treatment with 4 '-chloro-3,5-dihydroxystilbene and gradually increased through the $48 \mathrm{~h}$ time period. The intracellular ROS were increased approximately 1.6, 2.4, 2.7, 3.2, and 5.6 fold after treatment with 4 '-chloro-3,5-dihydroxystilbene for $1 \mathrm{~h}, 3 \mathrm{~h}, 6 \mathrm{~h}, 24 \mathrm{~h}$, and $48 \mathrm{~h}$, respectively (Figure 2A). To further characterize the relationship of ROS and cell death, two antioxidant agents, NAC and glutathione, were used to analyze the protective effect of $4^{\prime}$-chloro-3,5-dihydroxystilbenetreated cells. 4'-Chloro-3,5-dihydroxystilbene-induced ROS production was almost completely inhibited by $10 \mathrm{mmol} / \mathrm{L}$ $\mathrm{NAC}$ or $10 \mathrm{mmol} / \mathrm{L}$ glutathione (Figure $2 \mathrm{~B}$ ); however, these 
A
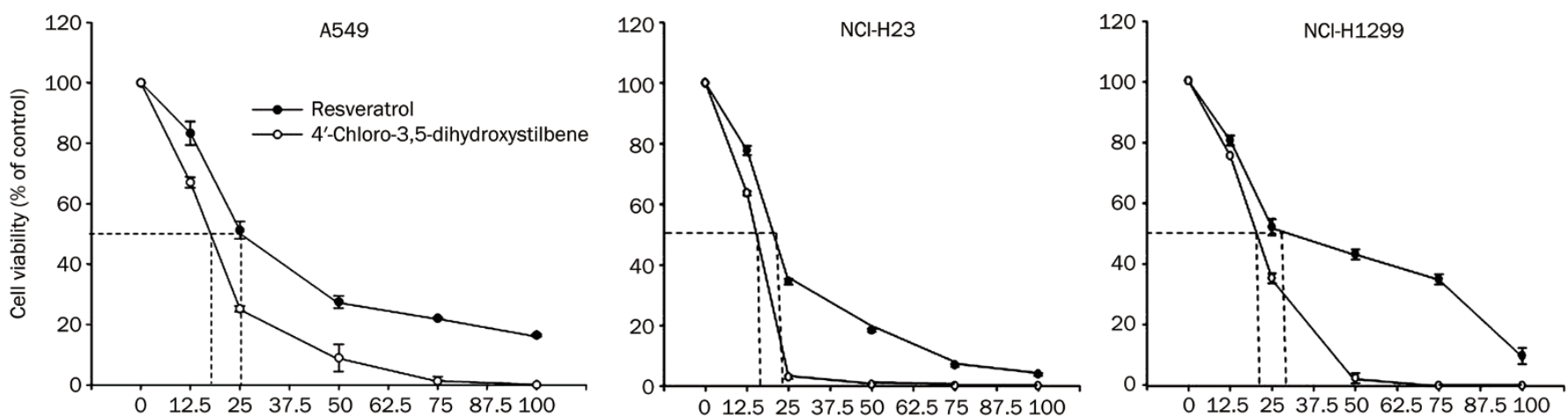

B
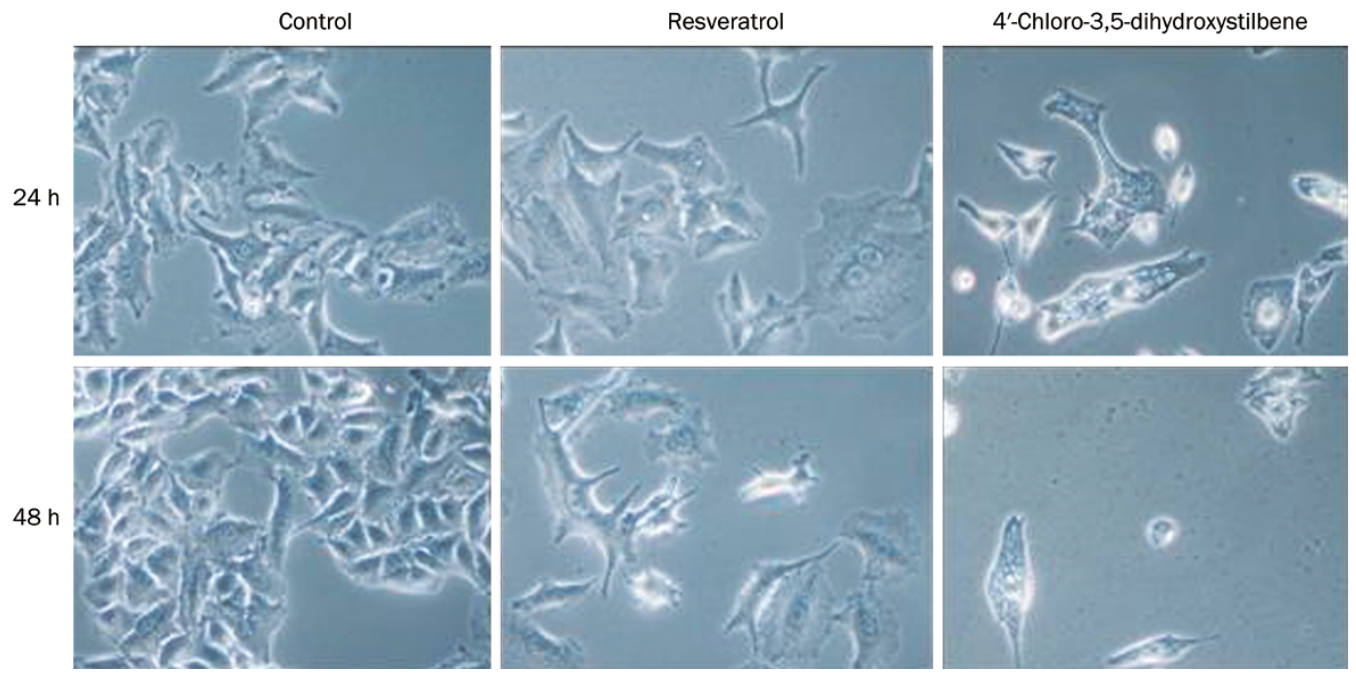

Figure 1. The cytotoxic $\mathrm{IC}_{50}$ and morphological changes in resveratrol- and 4'-chloro-3,5-dihydroxystilbene-treated A549 cells. (A) The cytotoxicity IC 50 of resveratrol and 4'-chloro-3,5-dihydroxystilbene. A549, NCl-H23, and NCl-H1299 cells were treated with various concentrations of resveratrol or 4'chloro-3,5-dihydroxystilbene for $48 \mathrm{~h}$. Cell numbers were calculated by the trypan blue dye exclusion method using a hemocytometer. The cell number of untreated cells was $100 \%$, and the other data were presented as the mean \pm SD from three independent experiments. (B) The morphological changes of A549 cells treated with resveratrol or 4'-chloro-3,5-dihydroxystilbene. A549 cells were treated with DMSO, $100 \mu \mathrm{mol} / \mathrm{L}$ resveratrol or $80 \mu \mathrm{mol} / \mathrm{L}$ 4'chloro-3,5-dihydroxystilbene for $24 \mathrm{~h}$ or $48 \mathrm{~h}$. The cells were photographed with an Axio Observer A1 phase-contrast microscope. Magnification $\times 200$.

two antioxidant agents could not prevent cell death (Figure 2C). This result indicated that the ROS elevation induced by $4^{\prime}$-chloro-3,5-dihydroxystilbene was not the main reason for cell death.

Effect of 4'-chloro-3,5-dihydroxystilbene on cell cycle distribution Because 4'-chloro-3,5-dihydroxystilbene inhibited the growth of A549 cells, we then analyzed the cell-cycle population distribution in A549 cells, with or without 4'-chloro-3,5-dihydroxystilbene. As shown in Figure $3 A$, the sub- $\mathrm{G}_{1}$ fraction in cells treated with $80 \mu \mathrm{mol} / \mathrm{L} \mathrm{4}$ '-chloro-3,5-dihydroxystilbene gradually increased to $18 \%$ and $43 \%$ at $24 \mathrm{~h}$ and $48 \mathrm{~h}$, respectively. The data indicated that 4'-chloro-3,5-dihydroxystilbene caused DNA fragmentation in a time-dependent manner. Before the formation of the sub- $G_{1}$ fraction, cells were initially accumulated in the $G_{2} / M$ phase, but those in the $G_{1}$ phase did not decrease when they were treated with 4'-chloro-3,5dihydroxystilbene. When $G_{2} / M$ phase arrest occurred, the $G_{1}$ phase ratio should have decreased if cells in $G_{1}$ continued to $S$ without M-returned cells. In our study, the $G_{1}$ phase ratio was similar to that of control cells, suggesting that $4^{\prime}$-chloro-3,5-dihydroxystilbene arrested cells in the $G_{1}$ and $G_{2} / M$ phases and that this arrest might result in sub- $\mathrm{G}_{1}$ formation. Resveratrol induced cell cycle arrest at the $G_{1}$ phase, which was different from the results obtained with 4'-chloro-3,5-dihydroxystilbene (Figure 3A). Western blot analysis (Figure 3B) showed that 4 '-chloro-3,5-dihydroxystilbene decreased the expression of cyclin D1 and cyclin D3, which might have caused $G_{1}$ phase arrest. 4'-Chloro-3,5-dihydroxystilbene also decreased cyclin B1 expression, which might have caused $\mathrm{G}_{2}$ phase arrest. 4'-Chloro-3,5-dihydroxystilbene decreased p21 expression, which suggested that cell cycle arrest was not mediated by the p53-p21 pathway. 
A
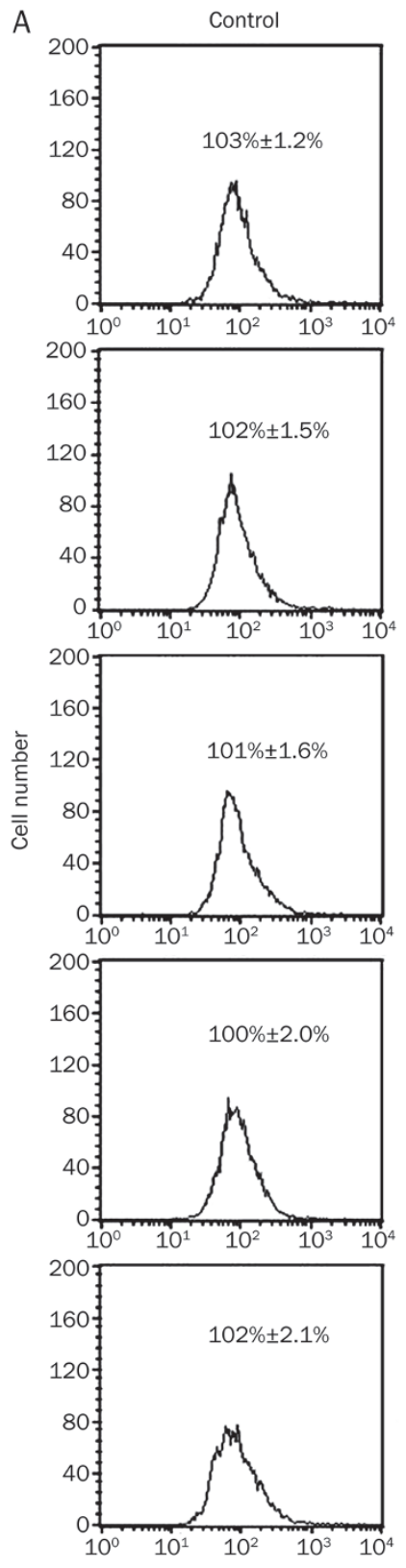

4'-Chloro-3,5-dihydroxystilbene
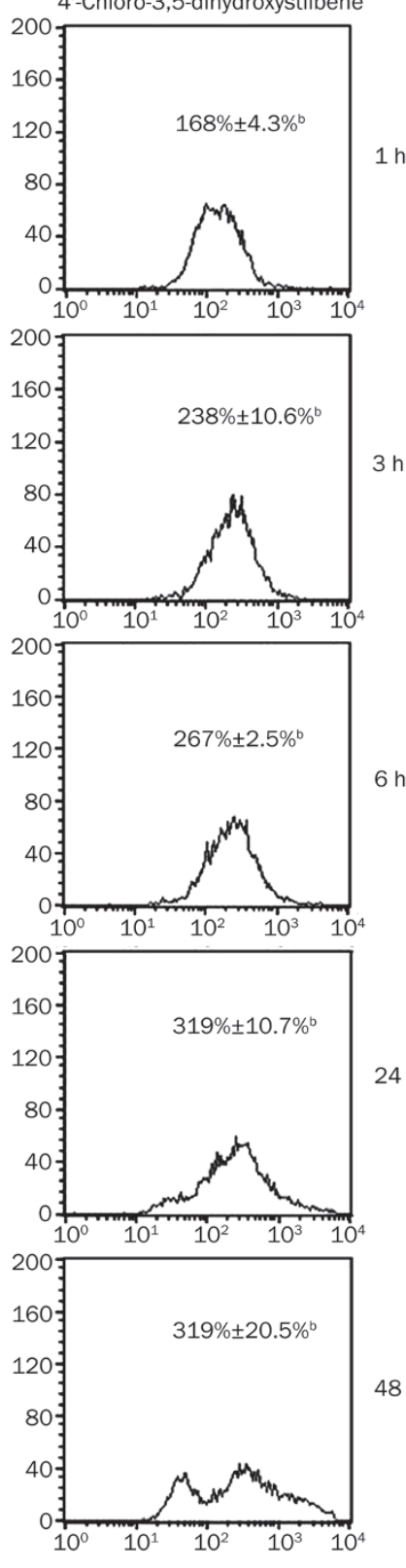

B

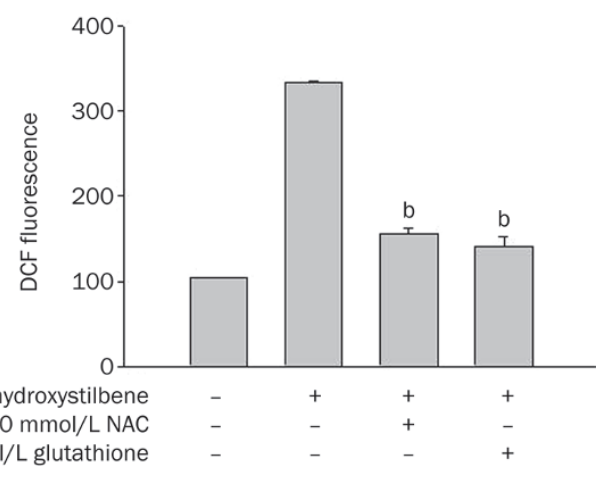

C

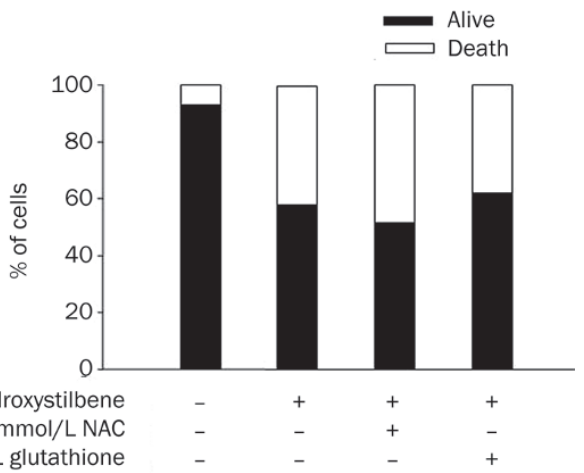

Figure 2. Effect of ROS on 4'-chloro-3,5-dihydroxystilbene-induced A549 cell death. (A) 4'-Chloro-3,5-dihydroxystilbene-induced ROS production. A549 cells were either untreated or treated with $80 \mu \mathrm{mol} / \mathrm{L}$ 4'-chloro-3,5-dihydroxystilbene for 1, 3, 6, 24, and $48 \mathrm{~h}$. Thirty minutes prior to harvesting, cells were incubated with $10 \mu \mathrm{mol} / \mathrm{L}$ DCF-DA. After incubation, the cells were harvested for analysis by FACS. The data in each panel represent the DCF fluorescence intensity within the cells. At each time point, the mean intensity of the control cells was at 100 and the other data were measured in this set condition. The values shown are the mean $\pm S D$ of three determinations. (B) Effect of antioxidants on 4'-chloro-3,5-dihydroxystilbene-induced ROS. $10 \mathrm{mmol} / \mathrm{L} \mathrm{NAC}$ or $10 \mathrm{mmol} / \mathrm{L}$ glutathione was added $1 \mathrm{~h}$ before treatment with $80 \mu \mathrm{mol} / \mathrm{L} 4^{\prime}$-chloro-3,5-dihydroxystilbene for $3 \mathrm{~h}$. Cells were harvested for analysis by FACS. The values shown are means \pm SD of three independent experiments. ${ }^{b} P<0.05$ vs the 4 '-chloro-3,5-dihydroxystilbenetreated group. (C) Effect of antioxidants on 4'-chloro-3,5-dihydroxystilbene-induced damage of cellular membrane integrity. The cells were exposed to $10 \mathrm{mmol} / \mathrm{L} \mathrm{NAC}$ or $10 \mathrm{mmol} / \mathrm{L}$ glutathione for $1 \mathrm{~h}$ before treatment with $80 \mu \mathrm{mol} / \mathrm{L}$ 4'-chloro-3,5-dihydroxystilbene for $36 \mathrm{~h}$. A549 cells were harvested and stained with propidium iodide and analyzed by FACS.

4'-Chloro-3,5-dihydroxystilbene induced apoptosis, which was a minor reason for cell death

Increased mitochondrial permeability is one of the mitochondria-dependent cell death pathways ${ }^{[14]}$. Therefore, we measured the mitochondrial permeability regulatory proteins Bcl-2 and Bax by Western blot analysis. Treatment of A549 cells with $80 \mu \mathrm{mol} / \mathrm{L} 4$ '-chloro-3,5-dihydroxystilbene caused a significant decrease in the anti-apoptotic protein $\mathrm{Bcl}-2$ in the 
A
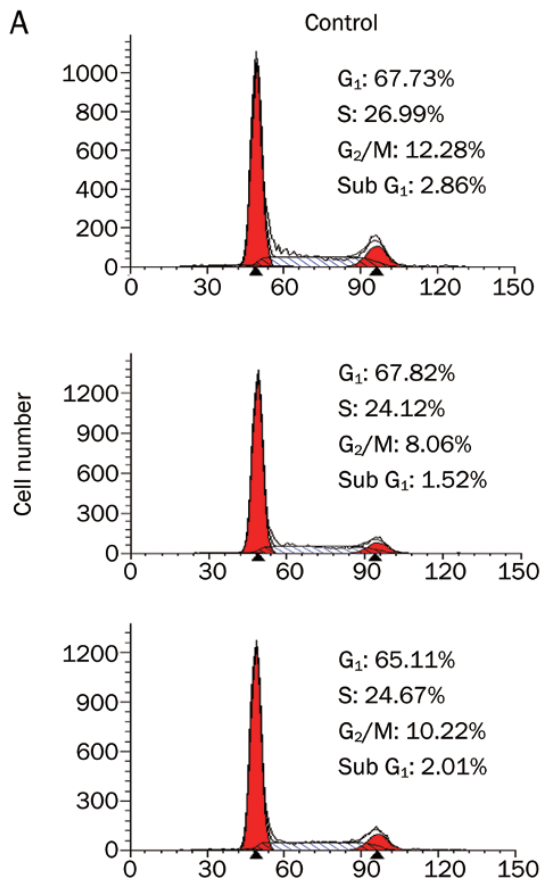

4'-Chloro-3,5-dihydroxystilbene
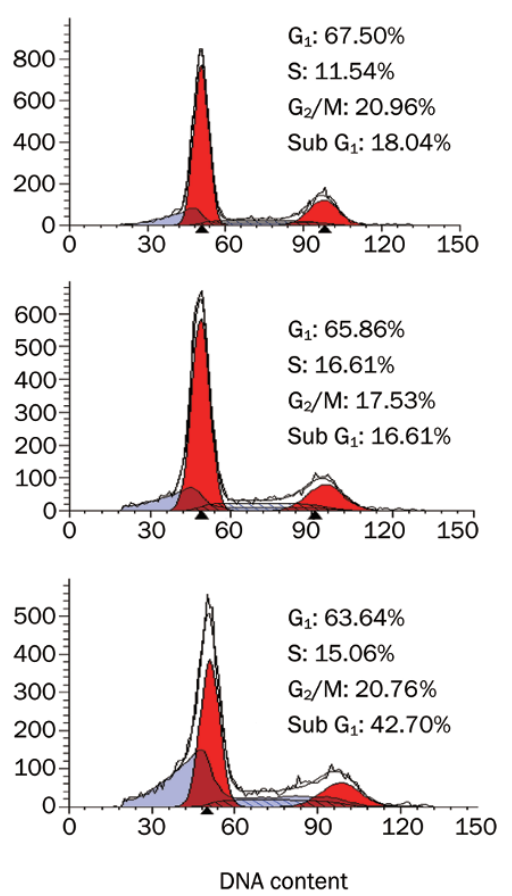

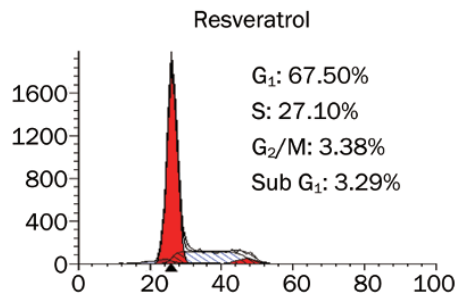

$24 \mathrm{~h}$

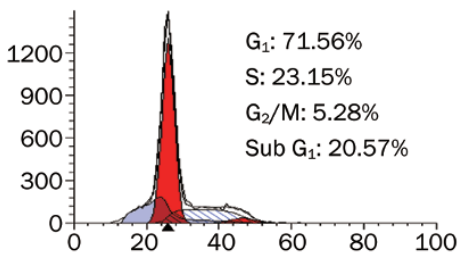

$36 \mathrm{~h}$

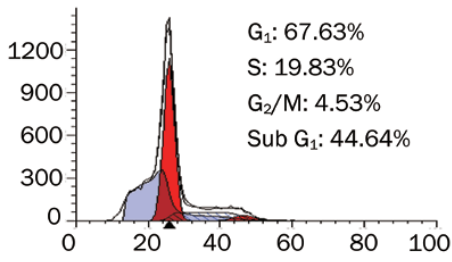

$48 \mathrm{~h}$
B

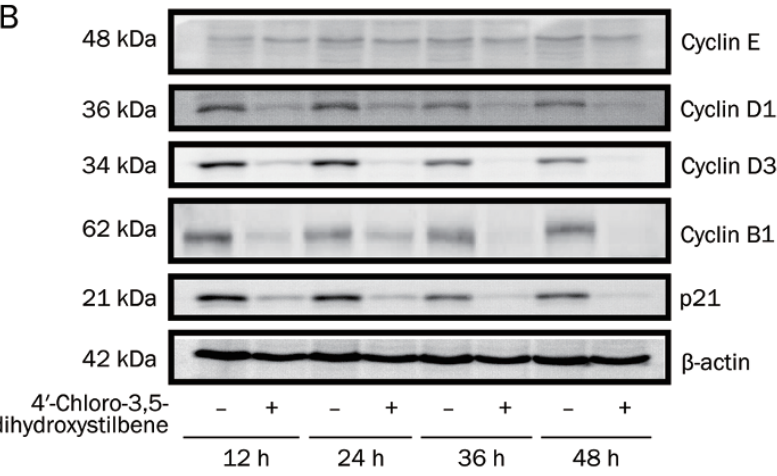

Figure 3. Effect of 4'-chloro-3,5-dihydroxystilbene and resveratrol on cell cycle distribution. (A) The cell cycle distribution is altered by 4'-chloro-3,5dihydroxystilbene or resveratrol treatment. A549 cells were treated with 80 $\mu \mathrm{mol} / \mathrm{L} 4$ '-chloro-3,5-dihydroxystilbene or $100 \mu \mathrm{mol} / \mathrm{L}$ resveratrol for 24,36 , or $48 \mathrm{~h}$. Cells were harvested, fixed with ethanol and stained with PI. The DNA content was analyzed by flow cytometry. A representative FACS scan chart of propidium iodide-stained $A 549$ cells shows the percentages of $G_{0} /$ $G_{1}, S, G_{2} / M$, and sub- $G_{1}$ cell cycle phases in each plot. The values shown are the mean of three determinations. (B) Time course of the 4'-chloro-3,5dihydroxystilbene-induced degradation of cyclins. A549 cells were treated with or without $80 \mu \mathrm{mol} / \mathrm{L}$ 4'-chloro-3,5-dihydroxystilbene for 12, 24, 36, and $48 \mathrm{~h}$. Cell lysates were harvested and analyzed by Western blotting with antibodies against cyclin E, cyclin D1, cyclin D3, cyclin B1 and p21. time period from $12 \mathrm{~h}$ to $48 \mathrm{~h}$ (Figure $4 \mathrm{~A}$ ), as well as a decrease in the pro-apoptotic protein Bax. Therefore, the detection of MMP by rodamine123 was performed, which showed that 4 '-chloro-3,5-dihydroxystilbene decreased MMP at $24 \mathrm{~h}$ and $48 \mathrm{~h}$ (Figure 4B). Because of the formation of the sub- $\mathrm{G}_{1}$ fraction and the decrease in MMP in $4^{\prime}$-chloro-3,5-dihydroxystilbene-treated cells, we then investigated whether $4^{\prime}$-chloro-3,5dihydroxystilbene induced the activation of apoptotic effector proteins. The breakdown products of PARP and procaspase- 3 were analyzed. Figure 5A shows that 4'-chloro-3,5-dihydroxystilbene induced both the cleavage of PARP and a decrease in procaspase-3. The change in these two proteins started after $24 \mathrm{~h}$ of treatment with $4^{\prime}$-chloro-3,5-dihydroxystilbene and persisted to $48 \mathrm{~h}$. A pan caspase inhibitor, Z-VAD-FMK, was then used to identify the relationship of apoptosis and cell death. It was shown that Z-VAD-FMK inhibited 4'-chloro-3,5dihydroxystilbene-induced sub-G1 formation (Figure 5B) and reversed PARP cleavage in a dose-dependent manner (Figure
5C). ROS are one of the reasons for cell apoptosis; we also analyzed the role of ROS in 4'-chloro-3,5-dihydroxystilbeneinduced sub- $\mathrm{G}_{1}$ formation. The results showed that two antioxidants inhibited the $4^{\prime}$-chloro-3,5-dihydroxystilbene-induced sub- $\mathrm{G}_{1}$ formation by $30 \%$ and the resveratrol-induced $s u b-\mathrm{G}_{1}$ formation by more than $50 \%$ (Figure $5 \mathrm{D}$ ). This result suggests that ROS are one of the reasons for 4'-chloro-3,5-dihydroxystilbene-induced apoptosis. Because these two antioxidants could not reverse 4'-chloro-3,5-dihydroxystilbene-induced cell death (Figure 2C), the reversal effect was further analyzed with Z-VAD-FMK. The results showed that Z-VAD-FMK only slightly reversed cell death (Figure 5E), even though apoptosis was almost completely inhibited by Z-VAD-FMK (Figure 5B, 5C). These data suggested that 4'-chloro-3,5-dihydroxystilbene-induced cell death was mediated by caspase-dependent apoptosis in a minor way. Because Z-VAD-FMK only slightly reversed 4'-chloro-3,5-dihydroxystilbene-induced cell death, ROS-inhibitor-reversible cell death might be too low to be 
A

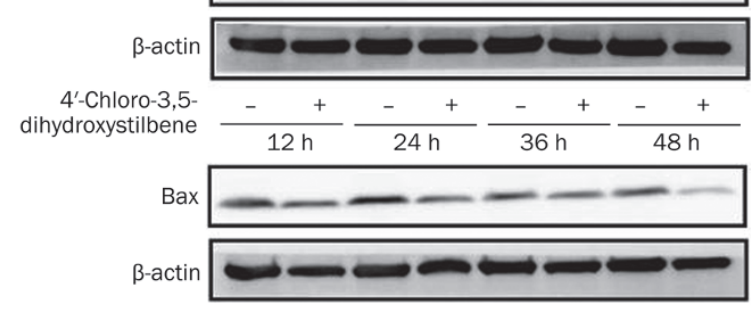

$\mathrm{B}$

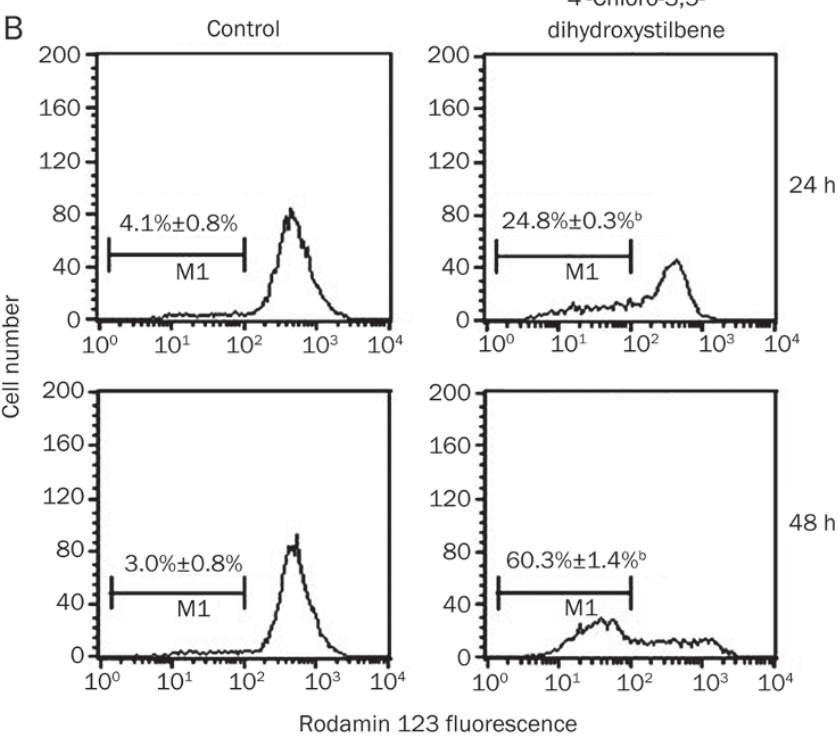

Figure 4. Effect of 4'-chloro-3,5-dihydroxystilbene on mitochondria membrane potential. (A) Time course of the 4'-chloro-3,5-dihydroxystilbene-induced degradation of $\mathrm{Bcl}-2$ and Bax. A549 cells were treated with or without $80 \mu \mathrm{mol} / \mathrm{L}$ 4'-chloro-3,5-dihydroxystilbene for 12, 24, 36 , and $48 \mathrm{~h}$. Cell lysates were harvested and analyzed by Western blotting with antibodies against Bcl-2, Bax and $\beta$-actin. (B) 4'-Chloro-3,5dihydroxystilbene decreased the MMP. A549 cells were treated with or without $80 \mu \mathrm{mol} / \mathrm{L} 4$ '-chloro-3,5-dihydroxystilbene for 24 or $48 \mathrm{~h}$. Cells were harvested and analyzed by FACS. A representative FACS scan chart shows the percentages of low MMP in each plot. The values shown are the mean $\pm S D$ of three determinations.

detected.

Induction of the autophagic early phenomenon by $4^{\prime}$-chloro-3,5dihydroxystilbene

If 4'-chloro-3,5-dihydroxystilbene-induced cell death was not totally mediated by apoptosis, the death could be caused by a non-apoptotic pathway, such as autophagy, necrosis or another process ${ }^{[15]}$. Based on the morphological changes induced by $4^{\prime}$-chloro-3,5-dihydroxystilbene, which showed vacuolation in the cells (Figure 1B), an autophagic process is likely ${ }^{[15]}$. We then attempted to detect the formation of acidic vacuoles in the cells. As shown in Figures 6A and 6B, 4'chloro-3,5-dihydroxystilbene increased the formation of intracellular acidic vacuoles. Next, we tried to confirm the autophagic phenomenon by more specific methods. First, we showed that 4'-chloro-3,5-dihydroxystilbene induced more obvious LC3-II formation than resveratrol (Figure 6C). Furthermore, the GFP-LC3 produced by transfected cells was used to confirm the process of autophagy ${ }^{[12,16]}$. Cytoplasmic LC3 proteins become localized within autophagic vacuoles when a cell begins autophagy ${ }^{[17,18]}$. Transient transfection with GFP-LC3 plasmid DNA was performed to express the GFPLC3 fusion protein in A549 cells. In the GFP-LC3-transfected A549 cells, GFP-LC3 proteins were found diffused through the whole cell (Figure 6D). After 4'-chloro-3,5-dihydroxystilbene treatment, GFP-LC3 became aggregated dots in the cells, suggesting that 4 -chloro-3,5-dihydroxystilbene caused the localization of LC3 and initiated the autophagic early phenomenon. Next, we used a pharmacological inhibitor to identify the relationship between autophagy and cell death. As shown in Figure 6E, 3-MA could partially reverse cell death, which suggested that the 4 '-chloro-3,5-dihydroxystilbene-induced cell death was partially mediated by autophagy. Furthermore, we used various protease inhibitors to analyze whether cell death was caused by an acidic lysosomal protease ${ }^{[19,20]}$. As shown in Figure 6E, two cathepsin inhibitors (CA074-Me and Z-FA-FMK), two serine protease inhibitors (TLCK and AEBSF) and one proteasome inhibitor (MG132) could not prevent cell death; only one serine protease inhibitor, TPCK, slightly reversed cell death. This result suggested that the $4^{\prime}$-chloro3,5-dihydroxystilbene-induced cell death was partially mediated by lysosome leakage, but not by proteasome activation. Caspase inhibitor Z-VAD-FMK also partially inhibited resveratrol-induced cell death.

\section{4'-Chloro-3,5-dihydroxystilbene inhibited proteasome activity in A549 cells}

While observing the morphological changes of MG132-treated cells, we found vacuole formation similar to that caused by 4'-chloro-3,5-dihydroxystilbene (Figure 7A). Because MG132 is a standard proteasome inhibitor used in anti-cancer studies, we tried to compare the biochemical effect of MG132 and 4 '-chloro-3,5-dihydroxystilbene treatment in cells. Figure $7 \mathrm{~B}$ showed the accumulation of ubiquitinated conjugates induced by $10 \mu \mathrm{mol} / \mathrm{L}$ and $50 \mu \mathrm{mol} / \mathrm{L}$ MG132. 4'-Chloro-3,5dihydroxystilbene also induced a dose-dependent increase in ubiquitinated conjugates. In an additional study, we analyzed the proteasome activity after 4 -chloro-3,5-dihydroxystilbene or MG132 treatment. This study showed that $4^{\prime}$-chloro-3,5dihydroxystilbene partially inhibited substrate cleavage by chymotrypsin-like and caspase-like proteasomes (Figure 7C).

\section{4'-Chloro-3,5-dihydroxystilbene retarded tumor growth in nude} mice

The anti-tumor effect of 4'-chloro-3,5-dihydroxystilbene was studied in nude mice inoculated with A549 cells. Figure 8 shows that $4^{\prime}$-chloro-3,5-dihydroxystilbene retarded tumor growth in vivo, indicating its potential as an anti-tumor drug.

\section{Discussion}

Resveratrol has been proposed as a potential chemothera- 
A

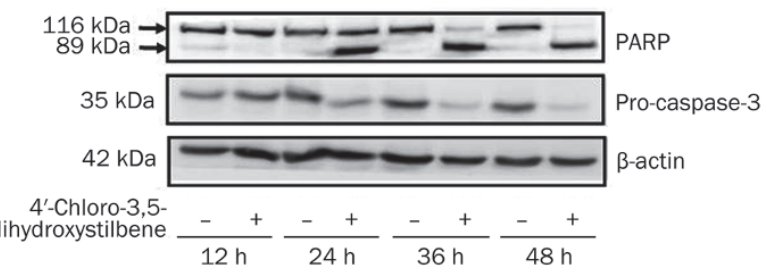

C

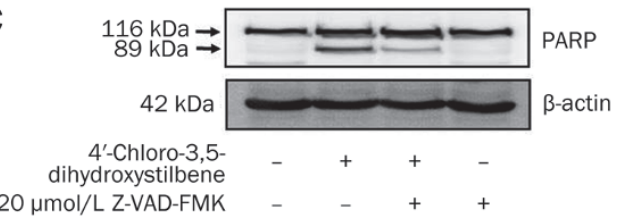

D

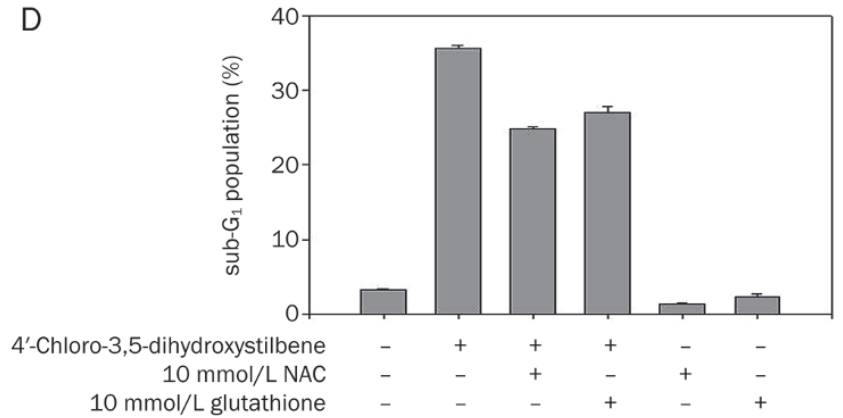

E

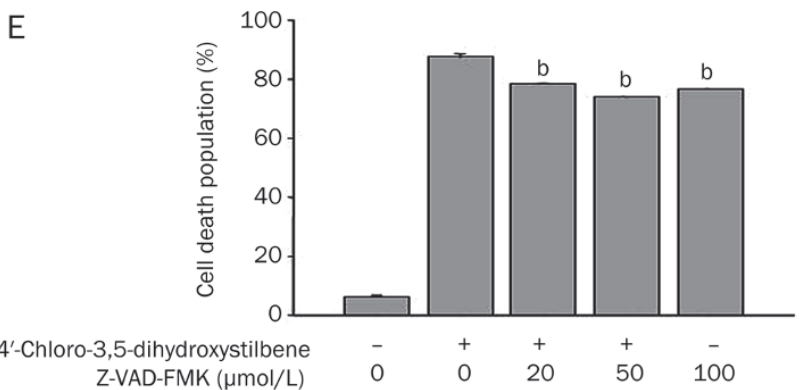

B

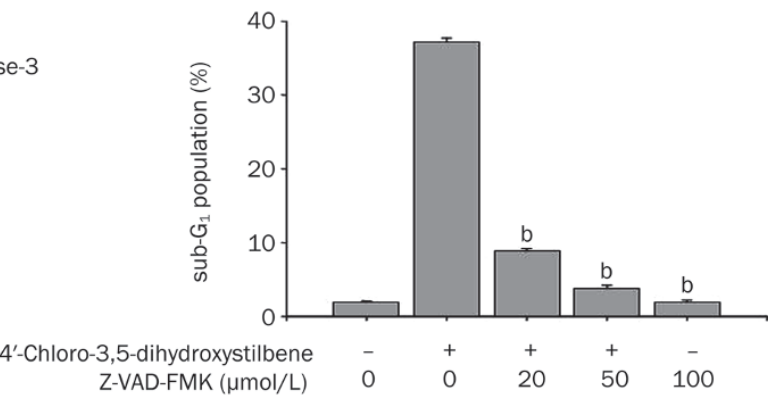

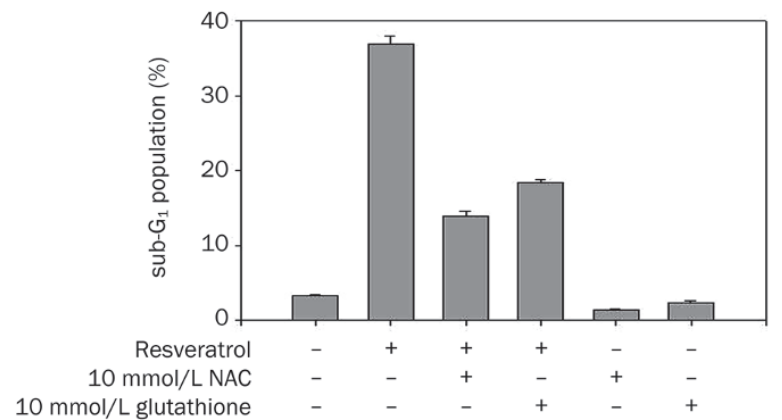

Figure 5. The apoptotic parameters of 4'-chloro-3,5-dihydroxystilbene-treated A549 cells. (A) Time course of the 4'-chloro-3,5-dihydroxystilbeneinduced degradation of PARP and procaspase-3. A549 cells were treated with or without $80 \mu \mathrm{mol} / \mathrm{L}$ 4'-chloro-3,5-dihydroxystilbene for 12, 24, 36, and $48 \mathrm{~h}$. Cell lysates were harvested and analyzed by Western blotting with antibodies against two forms of PARP, pre-cleavage caspase-3 and $\beta$-actin. (B) Effect of Z-VAD-FMK on 4'-chloro-3,5-dihydroxystilbene-induced sub-G ${ }_{1}$ formation. Z-VAD-FMK was added $1 \mathrm{~h}$ before treatment with 80 umol/L 4'chloro-3,5-dihydroxystilbene for $48 \mathrm{~h}$. Cells were harvested, fixed and stained with propidium iodide and analyzed by FACS. The values shown are the mean \pm SD of three determinations (C) Effect of Z-VAD-FMK on 4'-chloro-3,5-dihydroxystilbene-induced PARP cleavage. Z-VAD-FMK was added $1 \mathrm{~h}$ before treatment with $80 \mu \mathrm{mol} / \mathrm{L} 4^{\prime}$-chloro-3,5-dihydroxystilbene for $24 \mathrm{~h}$. Cell lysates were harvested and analyzed by Western blotting with antibodies against two forms of PARP and $\beta$-actin. (D) Effect of NAC and glutathione on 4'-chloro-3,5-dihydroxystilbene-induced sub-G $\mathrm{G}_{1}$ formation. NAC or glutathione was added $1 \mathrm{~h}$ before treatment with $80 \mu \mathrm{mol} / \mathrm{L} 4^{\prime}$-chloro-3,5-dihydroxystilbene or $100 \mu \mathrm{mol} / \mathrm{L}$ resveratrol for $48 \mathrm{~h}$. Cells were harvested, fixed and stained with propidium iodide and analyzed by FACS. The values shown are the mean \pm SD of three determinations. (E) Effect of Z-VAD-FMK on $4^{\prime}-$

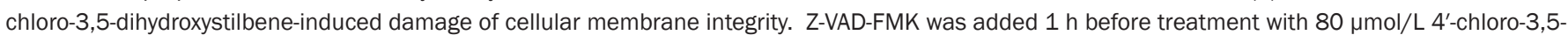
dihydroxystilbene for $48 \mathrm{~h}$. A549 cells were harvested and stained with propidium iodide and analyzed by FACS. The values shown are the mean \pm SD of three determinations. ${ }^{\mathrm{b}} \mathrm{P}<0.05$ vs the $4^{\prime}$-chloro-3,5-dihydroxystilbene-treated group.

peutic compound. Therefore, modification of the functional group of resveratrol was studied in this work. In the analysis of the structure-activity relationship, substitution of the hydroxyl group of resveratrol with a methoxy group did not seem to increase its cytotoxic activity (Supplementary information). On the contrary, substitution of the $4^{\prime}$-hydroxyl group of resveratrol with a halogen group potentiated cytotoxic activity (Supplementary information). When comparing the $\mathrm{IC}_{50}$ of resveratrol and 4'-chloro-3,5-dihydroxystilbene, the latter showed a higher potency of growth suppression in three lung cancer cell lines (Figure 1A). In the cell cycle analysis, 4'chloro-3,5-dihydroxystilbene induced cell arrest in the $\mathrm{G}_{1}$ 
A
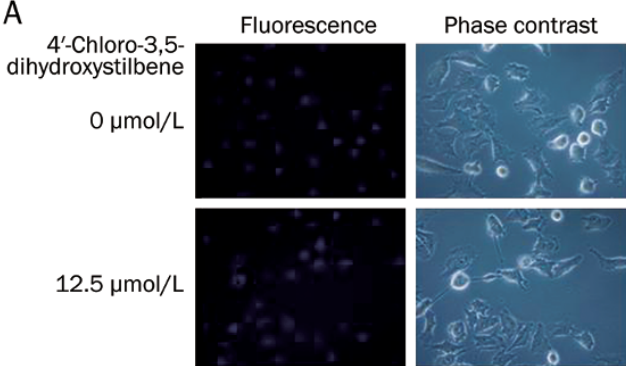

$25 \mu \mathrm{mol} / \mathrm{L}$
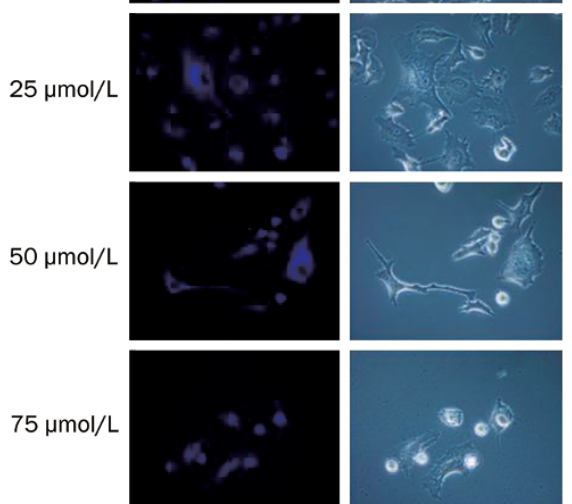

$100 \mu \mathrm{mol} / \mathrm{L}$
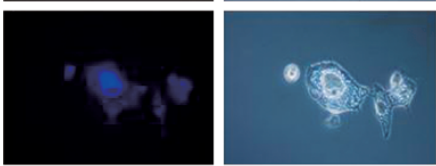

B
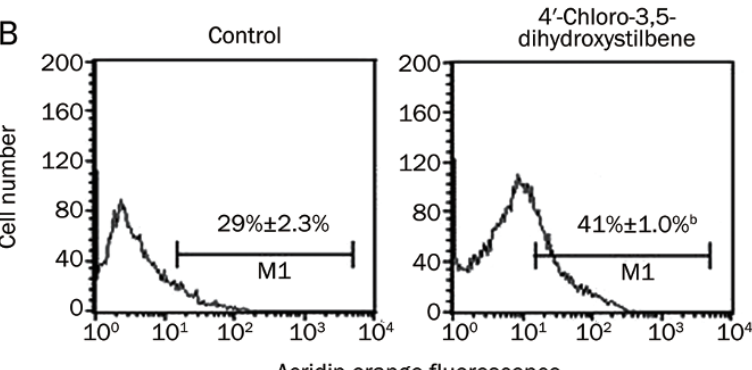

Acridin orange fluorescence

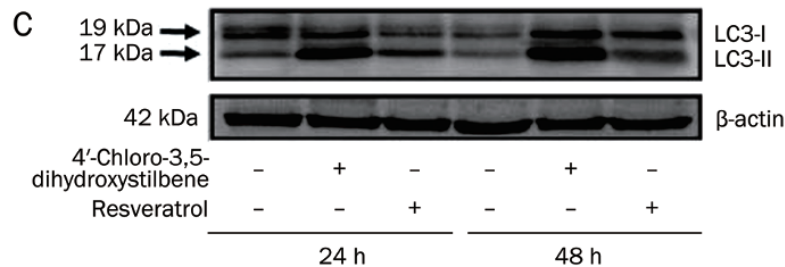

D

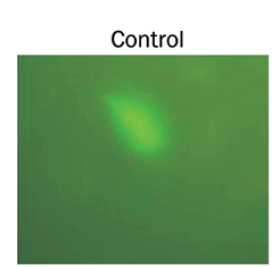

4'-Chloro-3,5-

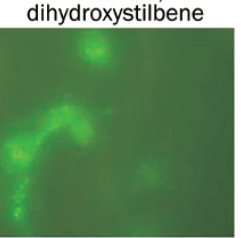

$24 \mathrm{~h}$
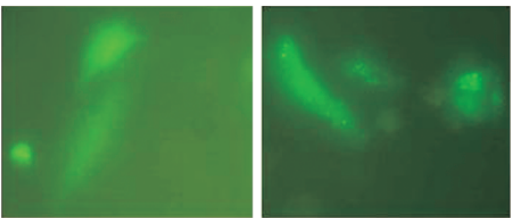

$30 \mathrm{~h}$

E

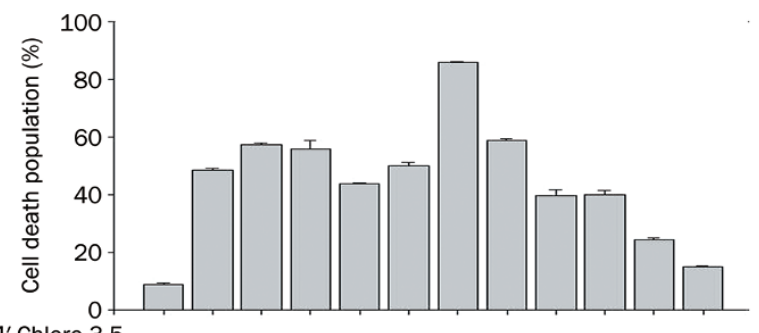

4'-Chloro-3,5 dihydroxystilbene $200 \mu \mathrm{mol} / L$ AEBSF $20 \mu \mathrm{mol} / \mathrm{L}$ Z-FA-FMK

$25 \mu \mathrm{mol} / \mathrm{L}$ TPCK

$25 \mu \mathrm{mol} / \mathrm{L}$ TLCK

$10 \mu \mathrm{mol} / \mathrm{L}$ MG132

$10 \mu \mathrm{mol} / \mathrm{L} \mathrm{CAO74-Me}$ $20 \mu \mathrm{mol} / \mathrm{L}$ Z-VAD-FMK

$10 \mathrm{mmol} / \mathrm{L} 3-\mathrm{MA}$ $100 \mu \mathrm{mol} / \mathrm{L}$ Resveratrol

F

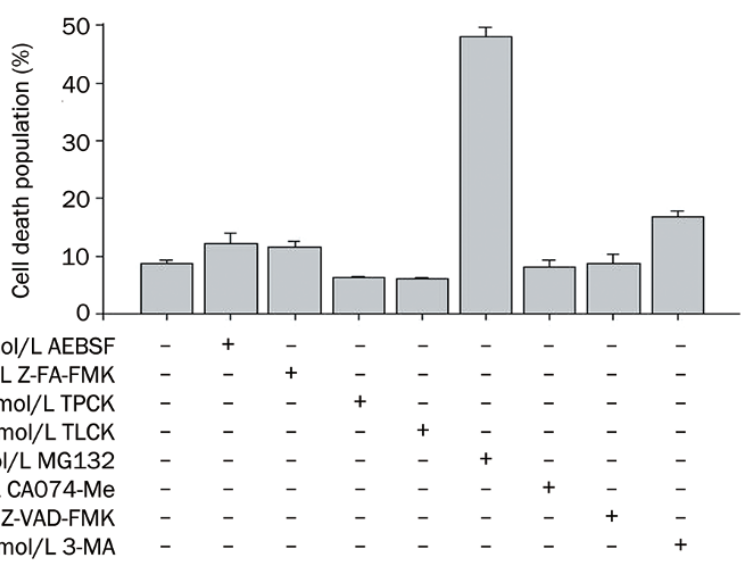

Figure 6. The autophagic parameters of 4'-chloro-3,5-dihydroxystilbene-treated A549 cells. (A) 4'-Chloro-3,5-dihydroxystilbene increased acidic vacuoles as determined by the MDC staining method. A549 cells were treated with or without $80 \mu \mathrm{mol} / \mathrm{L} 4^{\prime}$-chloro-3,5-dihydroxystilbene for $24 \mathrm{~h}$. Cells were then stained with MDC for photography. Magnification $\times 200$. (B) 4'-Chloro-3,5-dihydroxystilbene increased acidic vacuoles as determined by the acridine orange staining method. A549 cells were treated with or without $80 \mu \mathrm{mol} / \mathrm{L} 4^{\prime}$-chloro-3,5-dihydroxystilbene for $24 \mathrm{~h}$. Cells were then stained with acridine orange for flow cytometry analysis. ${ }^{b} P<0.05$ vs control. (C) 4 '-Chloro-3,5-dihydroxystilbene induces LC3-II formation. A549 cells were treated with or without $80 \mu \mathrm{mol} / \mathrm{L} 4^{\prime}$-chloro-3,5-dihydroxystilbene or $100 \mu \mathrm{mol} / \mathrm{L}$ resveratrol for $24 \mathrm{~h}$ and $48 \mathrm{~h}$. Cell lysates were harvested and analyzed by Western blotting with antibodies against LC3 and. (D) Time course of the 4'-chloro-3,5-dihydroxystilbene-induced aggregation of GFP-LC3 in A549 cells. A549 cells were transiently transfected with the GFP-LC3 plasmid. After transfection, the cells were treated with or without $80 \mu \mathrm{mol} / \mathrm{L} 44^{\prime}$-chloro-3,5dihydroxystilbene for $24 \mathrm{~h}$ and $30 \mathrm{~h}$. The cells were photographed with an Olympus IX70 fluorescent microscope. Magnification $\times 200$. (E and F) Effect of autophagy inhibitor (3-MA), protease inhibitors (AEBSF, Z-FA-FMK, TPCK, TLCK, CA074-Me), caspase inhibitor (Z-VAD-FMK) and proteasome inhibitor (MG132) on 4'-chloro-3,5-dihydroxystilbene-induced cell death. A549 cells were individually treated with DMSO or various inhibitors for $1 \mathrm{~h}$, then 80 $\mu \mathrm{mol} / \mathrm{L}$ 4'-chloro-3,5-dihydroxystilbene or $100 \mu \mathrm{mol} / \mathrm{L}$ resveratrol was added for $36 \mathrm{~h}$. A549 cells were harvested, stained with propidium iodide, and analyzed by FACS. The values shown are the mean \pm SD of three determinations. 

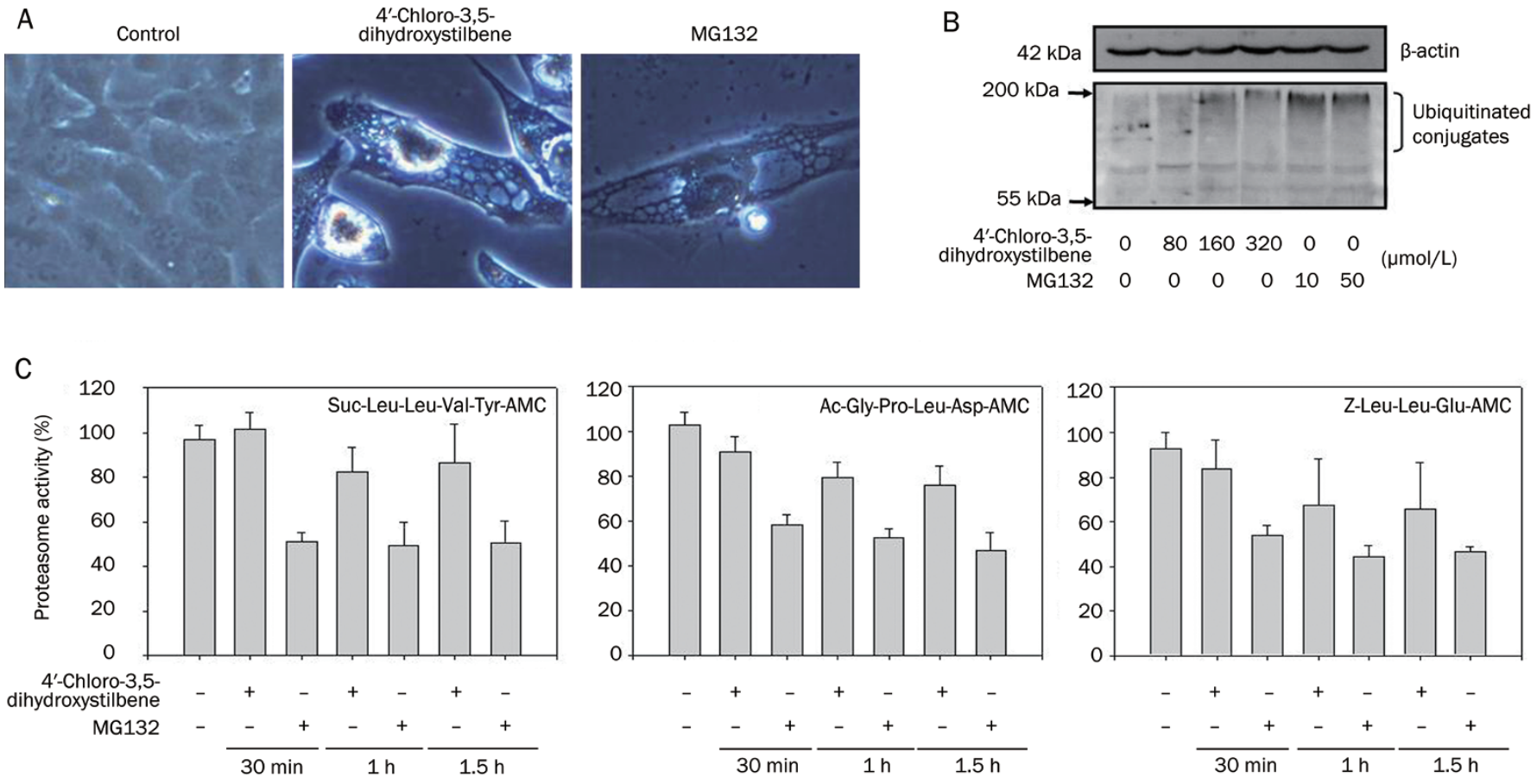

Figure 7. 4'-Chloro-3,5-dihydroxystilbene inhibited proteasome activity in A549 cells. (A) Morphological changes induced by 4'-chloro-3,5dihydroxystilbene and MG132. A549 cells were treated with $80 \mu \mathrm{mol} / \mathrm{L}$ 4'-chloro-3,5-dihydroxystilbene or $10 \mu \mathrm{mol} / \mathrm{L}$ MG132 for $48 \mathrm{~h}$ and the cells were photographed. Magnification $\times 200$. (B) Effect of 4'-chloro-3, 5-dihydroxystilbene on the accumulation of ubiquitinated conjugates. A549 cells were treated with various concentrations of 4'-chloro-3,5-dihydroxystilbene or MG132 for 60 min. Cell lysates were harvested and analyzed by Western blotting with antibodies against ubiquitin and $\beta$-actin. (C) Effect of 4'-chloro-3,5-dihydroxystilbene on proteasome activity. A549 cells were treated with $80 \mu \mathrm{mol} / \mathrm{L}$ 4'-chloro-3,5-dihydroxystilbene or $10 \mu \mathrm{mol} / \mathrm{L}$ MG132 for $30 \mathrm{~min}$ to $90 \mathrm{~min}$. Cell lysates were harvested and analyzed with proteasome fluorogenic peptide substrates.

and $\mathrm{G}_{2} / \mathrm{M}$ phases (Figure $3 \mathrm{~A}$ and $3 \mathrm{~B}$ ), but resveratrol mainly arrests cells in the $G_{1}$ and $S$ phases ${ }^{[21-24]}$. This result suggests that the simple functional group substitution of a natural compound can change its anti-cancer activity.

ROS are one of the factors for the induction of cell death, which can be prevented by antioxidants ${ }^{[25,26]}$. In this study, the production of ROS induced by $4^{\prime}$-chloro-3,5-dihydroxystilbene could be reduced by antioxidants (Figure 2B), but cell death could not be prevented (Figure 2C). Next, we showed that 4'-chloro-3,5-dihydroxystilbene induced apoptosis because it induced a sub- $\mathrm{G}_{1}$ formation (Figure $3 \mathrm{~A}$ ), a decrease in mitochondria membrane potential (Figure $4 \mathrm{~B}$ ) and the degradation of PARP and procaspase-3 (Figure 5A). The decrease in MMP is one of the reasons for cell death ${ }^{[27]}$, and the Bcl-2 family proteins are one of the groups that regulate $\mathrm{MMP}^{[14]}$. Resveratrol has been reported to induce apoptosis through the Bcl-2mitochondria pathway ${ }^{[28]}$, but $4^{\prime}$-chloro-3,5-dihydroxystilbene induced a reduction of both the $\mathrm{Bcl}-2$ and the Bax proteins (Figure 4A). Therefore, the MMP was directly analyzed, and we showed that it was decreased by $4^{\prime}$-chloro-3,5-dihydroxystilbene (Figure 4B). PARP, a ubiquitous housekeeping enzyme, signals the presence of DNA damage by catalyzing the addition of ADP-ribose units to DNA, histones and various DNA repair enzymes and facilitates DNA repair ${ }^{[29]}$. In general, apoptosis is activated by PARP fragmentation, which

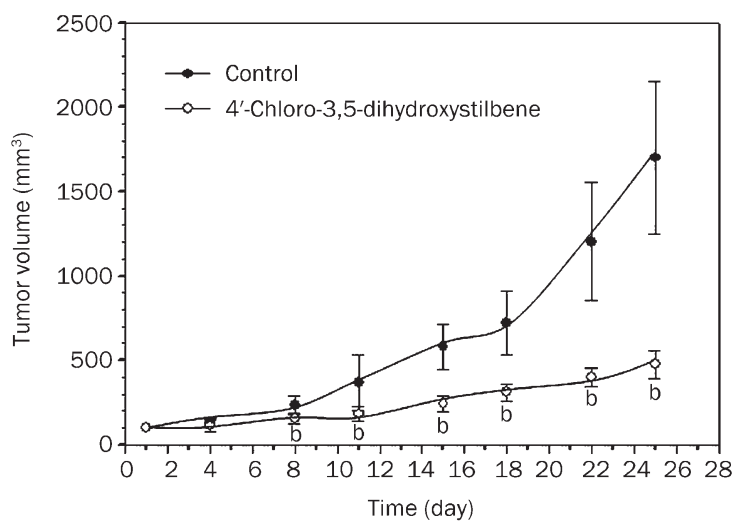

Figure 8. Anti-tumor effect of 4'-chloro-3,5-dihydroxystilbene in vivo. Fiveweek-old female nude mice were injected sc with $1 \times 10^{7}$ A549 cells in $100 \mu \mathrm{L}$ of Matrigel in one rear flank. When the tumor volume reached $100 \mathrm{~mm}^{3}$, mice were given vehicle ( $n=7$, control) or $50 \mathrm{mg} / \mathrm{kg}$ of $4^{\prime}$-chloro3,5-dihydroxystilbene $(n=7)$ ip once daily from day 1 to 4 and day 7 to 10 . Tumor volume was calculated by the formula $\mathrm{mm}^{3}=$ (the long axis) $\times$ (the short axis $)^{2} / 2$. ${ }^{\mathrm{b}} \mathrm{P}<0.05$ vs control.

occurs through activated caspase-3, therefore, we used the pan caspase inhibitor Z-VAD-FMK to block caspase activation. Although Z-VAD-FMK blocked the 4'-chloro-3,5-dihy- 
droxystilbene-induced sub- $\mathrm{G}_{1}$ formation (Figure $5 \mathrm{~B}$ ), it only slightly reduced the 4'-chloro-3,5-dihydroxystilbene-induced cell death (Figure 5E). This result suggests that there are other mechanisms besides apoptosis that induce cell death by 4'-chloro-3,5-dihydroxystilbene.

Due to the formation of vacuoles in cells after $4^{\prime}$-chloro-3,5dihydroxystilbene treatment, we thought that autophagocytosis might have been induced. Autophagy is a process during which intracellular autophagosomes form and sequester cellular contents for degradation ${ }^{[18]}$. Microtubule-associated protein light chain 3 (LC3), the mammalian ortholog of yeast Atg8, is a characteristic protein that aggregates on the membrane of autophagic vesicles ${ }^{[12]}$. Autophagy can promote cell adaption and survival under stresses such as starvation and pathogen infection, but it can also induce cell death under some conditions. In this study, we showed that $4^{\prime}$-chloro3,5-dihydroxystilbene induced autophagy in A549 cells because it caused LC3-II formation (Figure 6C) and GFP-LC3 aggregation (Figure 6D). Chemicals such as tamoxifen ${ }^{[30]}$, sodium butyrate $^{[31]}$, rapamycin ${ }^{[32]}$, and resveratrol ${ }^{[33]}$ induce autophagic cell death, and provide a non-apoptotic cell death during cancer treatment. In contrast, autophagy has also been reported to be a protective mechanism in nelfinavir-induced cell death ${ }^{[34]}$. In this study, we showed that $4^{\prime}$-chloro-3,5dihydroxystilbene induced the autophagic phenomenon. Like the apoptosis inhibitor, the autophagic inhibitor 3-MA and lysosomal protease inhibitor TPCK could partially reverse cell death (Figure 6E).

Since both 4'-chloro-3,5-dihydroxystilbene and the proteasome inhibitor MG132 cause specific vacuole formation, they may use the same mechanism. The ubiquitin-proteasome system is a new target for cancer therapy ${ }^{[35]}$. There are three types of peptidase activity in the proteolytic core of the $26 \mathrm{~S}$ proteasome complex, and they include the chymotrypsin-like, trypsin-like and caspase-like activities ${ }^{[36]}$. In this study, we found that MG132 and 4'-chloro-3,5-dihydroxystilbene inhibited the chymotrypsin-like and caspase-like proteasome activities (Figure 7C), but they did not inhibit the trypsin-like proteasome activity (data not shown). Proteasome inhibition by 4 '-chloro-3,5-dihydroxystilbene provides additional evidence of its cytotoxicity. Finally, we studied the anti-tumor activity in vivo and showed that $4^{\prime}$-chloro-3,5-dihydroxystilbene significantly retarded tumor growth in mice (Figure 8). These results suggest that 4 '-chloro-3,5-dihydroxystilbene, a resveratrol derivative, has the potential to treat human non-small-cell lung adenocarcinoma through multiple mechanisms.

\section{Acknowledgements}

This work was supported by grants from the National Science Council of Taiwan (NSC97-2320-B-415-002) and the Buddhist Tzuchi Dalin General Hospital (DTCRD97(2)-08).

\section{Author contribution}

Yi-wen LIU and Kun-wei TSAI designed the research and wrote the paper. Jin-yi WU, Jia-jen SHEE, Yi-zhen LI, Chinghsein CHEN, and Jing-jing CHUANG performed the research.
Jin-yi WU contributed new reagents. Jia-jen SHEE and Yi-wen LIU analyzed the data.

\section{References}

1 Burns J, Yokota T, Ashihara H, Lean ME, Crozier A. Plant foods and herbal sources of resveratrol. J Agric Food Chem 2002; 50: 3337-40.

2 Hain R, Reif HJ, Krause E, Langebartels R, Kindl H, Vornam B, et al. Disease resistance results from foreign phytoalexin expression in a novel plant. Nature 1993; 361: 153-6.

3 Pace-Asciak CR, Hahn S, Diamandis EP, Soleas G, Goldberg DM. The red wine phenolics trans-resveratrol and quercetin block human platelet aggregation and eicosanoid synthesis: implications for protection against coronary heart disease. Clin Chim Acta 1995; 235 : 207-19.

4 Djoko B, Chiou RY, Shee JJ, Liu YW. Characterization of immunological activities of peanut stilbenoids, arachidin-1, piceatannol, and resveratrol on lipopolysaccharide-induced inflammation of RAW 264.7 macrophages. J Agric Food Chem 2007; 55: 2376-83.

5 Belguendouz L, Fremont L, Linard A. Resveratrol inhibits metal iondependent and independent peroxidation of porcine low-density lipoproteins. Biochem Pharmacol 1997; 53: 1347-55.

6 Jang M, Cai L, Udeani GO, Slowing KV, Thomas CF, Beecher CW, et al. Cancer chemopreventive activity of resveratrol, a natural product derived from grapes. Science 1997; 275: 218-20.

7 Aggarwal BB, Bhardwaj A, Aggarwal RS, Seeram NP, Shishodia S, Takada Y. Role of resveratrol in prevention and therapy of cancer: preclinical and clinical studies. Anticancer Res 2004; 24: 2783-840.

8 Kundu JK, Surh YJ. Cancer chemopreventive and therapeutic potential of resveratrol: mechanistic perspectives. Cancer Lett 2008; 269: 243-61.

9 Sale S, Verschoyle RD, Boocock D, Jones DJ, Wilsher N, Ruparelia $\mathrm{KC}$, et al. Pharmacokinetics in mice and growth-inhibitory properties of the putative cancer chemopreventive agent resveratrol and the synthetic analogue trans 3,4,5,4'-tetramethoxystilbene. Br J Cancer 2004; 90: 736-44.

10 Jemal A, Siegel R, Ward E, Hao Y, Xu J, Murray T, et al. Cancer statistics, 2008. CA Cancer J Clin 2008; 58: 71-96.

11 Chen LG, Hung LY, Tsai KW, Pan YS, Tsai YD, Li YZ, et al. Wogonin, a bioactive flavonoid in herbal tea, inhibits inflammatory cyclooxygenase-2 gene expression in human lung epithelial cancer cells. Mol Nutr Food Res 2008; 52: 1349-57.

12 Kabeya Y, Mizushima N, Ueno T, Yamamoto A, Kirisako T, Noda T, et al. LC3, a mammalian homologue of yeast Apg8p, is localized in autophagosome membranes after processing. Embo J 2000; 19: 5720-8.

13 Alexandre J, Batteux F, Nicco C, Chereau C, Laurent A, Guillevin L, et al. Accumulation of hydrogen peroxide is an early and crucial step for paclitaxel-induced cancer cell death both in vitro and in vivo. Int J Cancer 2006; 119: 41-8.

14 Sharpe JC, Arnoult D, Youle RJ. Control of mitochondrial permeability by Bcl-2 family members. Biochim Biophys Acta 2004; 1644: 107-13.

15 Okada H, Mak TW. Pathways of apoptotic and non-apoptotic death in tumour cells. Nat Rev Cancer 2004; 4: 592-603.

16 Mizushima N, Yamamoto A, Hatano M, Kobayashi Y, Kabeya Y, Suzuki $\mathrm{K}$, et al. Dissection of autophagosome formation using Apg5-deficient mouse embryonic stem cells. J Cell Biol 2001; 152: 657-68.

17 Mizushima N, Yamamoto A, Matsui M, Yoshimori T, Ohsumi Y. In vivo analysis of autophagy in response to nutrient starvation using transgenic mice expressing a fluorescent autophagosome marker. Mol Biol Cell 2004; 15: 1101-11. 
18 Kondo Y, Kanzawa T, Sawaya R, Kondo S. The role of autophagy in cancer development and response to therapy. Nat Rev Cancer 2005; 5: 726-34.

19 Kroemer G, Jaattela M. Lysosomes and autophagy in cell death control. Nat Rev Cancer 2005; 5: 886-97.

20 O'Sullivan MP, O'Leary S, Kelly DM, Keane J. A caspase-independent pathway mediates macrophage cell death in response to Mycobacterium tuberculosis infection. Infect Immun 2007; 75 : 1984-93.

21 Kim YA, Lee WH, Choi TH, Rhee SH, Park KY, Choi YH. Involvement of $221^{\text {WAF1/CIP1 }}, \mathrm{pRB}$, Bax and NF-kappaB in induction of growth arrest and apoptosis by resveratrol in human lung carcinoma A549 cells. Int J Oncol 2003; 23: 1143-9.

22 Schneider Y, Vincent F, Duranton B, Badolo L, Gosse F, Bergmann C, et al. Anti-proliferative effect of resveratrol, a natural component of grapes and wine, on human colonic cancer cells. Cancer Lett 2000; 158: 85-91.

23 Joe AK, Liu H, Suzui M, Vural ME, Xiao D, Weinstein IB. Resveratrol induces growth inhibition, S-phase arrest, apoptosis, and changes in biomarker expression in several human cancer cell lines. Clin Cancer Res 2002; 8: 893-903.

24 Bernhard D, Tinhofer I, Tonko M, Hubl H, Ausserlechner MJ, Greil R, et al. Resveratrol causes arrest in the S-phase prior to Fas-independent apoptosis in CEM-C7H2 acute leukemia cells. Cell Death Differ 2000; 7: 834-42.

25 Pelicano H, Carney D, Huang P. ROS stress in cancer cells and therapeutic implications. Drug Resist Updat 2004; 7: 97-110.

26 Valko M, Rhodes CJ, Moncol J, Izakovic M, Mazur M. Free radicals, metals and antioxidants in oxidative stress-induced cancer. Chem Biol Interact 2006; 160: 1-40.

27 Ly JD, Grubb DR, Lawen A. The mitochondrial membrane potential (deltapsi(m)) in apoptosis; an update. Apoptosis 2003; 8: 115-28.
28 Tinhofer I, Bernhard D, Senfter M, Anether G, Loeffler M, Kroemer $\mathrm{G}$, et al. Resveratrol, a tumor-suppressive compound from grapes, induces apoptosis via a novel mitochondrial pathway controlled by Bcl-2. Faseb J 2001; 15: 1613-5.

29 Malanga M, Althaus FR. The role of poly(ADP-ribose) in the DNA damage signaling network. Biochem Cell Biol 2005; 83: 354-64.

30 Bursch W, Ellinger A, Kienzl H, Torok L, Pandey S, Sikorska M, et al. Active cell death induced by the anti-estrogens tamoxifen and ICl 164 384 in human mammary carcinoma cells (MCF-7) in culture: the role of autophagy. Carcinogenesis 1996; 17: 1595-607.

31 Shao Y, Gao Z, Marks PA, Jiang X. Apoptotic and autophagic cell death induced by histone deacetylase inhibitors. Proc Natl Acad Sci USA 2004; 101: 18030-5.

32 Takeuchi H, Kondo Y, Fujiwara K, Kanzawa T, Aoki H, Mills GB, et al. Synergistic augmentation of rapamycin-induced autophagy in malignant glioma cells by phosphatidylinositol 3-kinase/protein kinase B inhibitors. Cancer Res 2005; 65: 3336-46.

33 Opipari AW Jr, Tan L, Boitano AE, Sorenson DR, Aurora A, Liu JR. Resveratrol-induced autophagocytosis in ovarian cancer cells. Cancer Res 2004; 64: 696-703.

34 Gills JJ, Lopiccolo J, Tsurutani J, Shoemaker RH, Best CJ, AbuAsab MS, et al. Nelfinavir, a lead HIV protease inhibitor, is a broadspectrum, anticancer agent that induces endoplasmic reticulum stress, autophagy, and apoptosis in vitro and in vivo. Clin Cancer Res 2007; 13: 5183-94.

35 Bazzaro M, Lee MK, Zoso A, Stirling WL, Santillan A, Shih le M, et al. Ubiquitin-proteasome system stress sensitizes ovarian cancer to proteasome inhibitor-induced apoptosis. Cancer Res 2006; 66: 3754-63.

36 Kisselev AF, Callard A, Goldberg AL. Importance of the different proteolytic sites of the proteasome and the efficacy of inhibitors varies with the protein substrate. J Biol Chem 2006; 281: 8582-90. 